\title{
PROTAGONISMO INDÍGENA, XAMANISMO E CRIAÇÃO POÉTICA
}

\section{Fernando Alves da Silva Júnior}

Resumo: O recente avanço nas publicações de autoria indigena é um fato a ser comemorado, tanto pelo engajamento das comunidades originárias das Américas em construírem sua história, quanto a escrita tornar-se uma entrada política no mundo Ocidental. Se historicamente seus valores foram vilipendiados, com a escrita o sujeito autóctone assume a própria voz. Compreendendo que na Amazônia existe um protagonismo não-ocidental de criação poética, este trabalho objetiva apresentar algumas características dos saiti marubo e relacioná-las ao xamanismo, conforme as traduções apresentadas por Cesarino no livro Quando a Terra deixou de falar. Os saiti são longos cantos-mitos, textos criativos de viés poético, que se estruturam segundo uma fórmula de composição, segundo Cesarino, o surgimento-deslocamento-estabelecimento.

Palavras-chave: Xamanismo. Protagonismo indígena. Criação poética.

\section{INTRODUÇÃo}

Posso ser o que você é sem deixar o que eu sou (TERENA, 1981, p. 5) ${ }^{1}$.

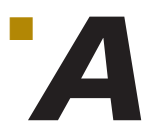

recente participação indígena em ações de cunho político-cultural é um fato a ser comemorado, tanto pelo interesse das comunidades da floresta em se engajarem na construção de sua história ${ }^{2}$, quanto pelo

1 Ver arquivo digital da Folha de S.Paulo sobre a criação da União das Nações Indígenas (UNI). Disponível em: https://acervo.folha. com.br/leitor.do?numero=7367\&keyword=comprometidas\&anchor $=4867533 \&$ origem $=$ busca \&pd=05358cdd68920 bbca2fa6adab 1c0ac08. Acesso em: 25 abr. 2019. Cf. também Tukano (2018).

2 Há o jargão eurocêntrico colonialista de que os povos do Novo Mundo são povos sem história, logo o povo que aportou nessa terra era um povo com história, dono da escrita e, por isso, nada mais legítimo que fosse autorizado a escrever sobre o outro. O Ocidente só foi possível com a criação do outro do ocidente (CLASTRES, 1988, p. 133). 
fato de a escrita tornar-se uma entrada política no mundo ocidental para grupos etnicamente minoritários colocados à margem dos sistemas de produção de conhecimento. Se contarmos que a chegada dos europeus à América iniciou-se na virada do século XV para o XVI, notaremos que a insurgência do índio nos debates políticos, de modo cada vez mais expressivo, se contado desde meados do século XX aos dias atuais, é um avanço recente. Como sabemos, o texto escrito é um documento naquilo que implica a manutenção dos valores culturais, ao mesmo tempo que é um gesto do protagonismo desses agentes sociais engajados em atividades que visam tornar visivel seu modo de pensar. Tanto é, que tal envolvimento com a escrita motivou, por exemplo, os Marubo a criarem o termo docomento para as produções elaboradas em parceria com os pesquisadores que, conforme explica Cesarino (2013b, p. 18), é precisamente aquilo "que se deve mostrar aos chefes dos brancos para que se garanta a integridade das terras, para que o saber seja reconhecido, para que os Marubo sejam enfim tratados com o devido respeito". O gesto é de autoafirmação, um protagonismo que ecoa vozes historicamente silenciadas. Como muito bem observou Eunice Durham (2004, p. 303), em O lugar do indio, "a cultura e a sobrevivência física dos índios implica uma incorporação e apropriação de valores da civilização ocidental".

Vale lembrar que pelo menos dois aspectos foram somados para que esse protagonismo tenha se edificado: 1. a educação escolar indígena, por meio das escolas da floresta, que abriu uma vereda para a aquisição da escrita por um número cada vez mais crescente de comunidades indígenas - o estado do Acre acumula uma grande experiência de ensino com comunidades indígenas e a pesquisa de Nietta Monte (1996) aponta o início da década de 1980 como o ponto de partida das primeiras demandas das lideranças Huni Kuĩ, a Funai e a Comissão Pró-Índio do Acre (CPI/AC) para a construção da escola indígena acreana; 2. de certo modo, a Lei $n^{\circ} 11.645^{3}$, de 10 de março de 2008 - que altera o art. 26A da Lei $\mathrm{n}^{\circ} 9.394^{4}$, de 20 de dezembro de 1996, modificada pela Lei $n^{\circ} 10.639^{5}$, de 9 de janeiro de 2003, que estabelece as Diretrizes e Bases da Educação Nacional - incluiu no currículo oficial dos estabelecimentos de ensino fundamental e médio, públicos e privados, a obrigatoriedade da temática "história e cultura afro-brasileira e indígena" gerando, com isso, o interesse das editoras em publicarem obras escritas por indígenas. Por isso, podemos dizer que o saldo é positivo após dez anos da publicação da Lei $\mathrm{n}^{\circ} 11.645 \mathrm{sem}$, por outro lado, deixar de reconhecer o papel da militância que traça um extenso percurso de luta em favor dos grupos indígenas. Desse modo, a escrita é a arena privilegiada para que as vozes emudecidas rompam a mordaça e a literatura, como explica Graça Graúna (2013, p. 15), é "um lugar de confluência de vozes silenciadas e exiladas (escritas) ao longo dos mais de 500 anos de colonização".

$\mathrm{O}$ indigena ganha sua voz porque a havia perdido, ou melhor, nunca a possuiu por ela ter sido usurpada desde o primeiro contato, um povo sem boca, para lembrar Achugar (2006, p. 20), um povo que por não ter boca existia no discurso do outro, o outro que falava/fala pelo indígena tornando-o transparente, criando estereótipos, petrificando predicativos negativos. Álvaro Tukano re-

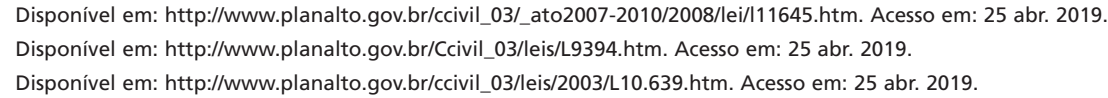


lata que seu pai havia percebido que era preciso educar o filho na escola do branco para que fosse possível um diálogo com o colonizador. Para manter suas tradições, era urgente que o jovem Álvaro aprendesse a ler e a escrever, como ele diz: "para poder falar de nossas coisas, tecer novos aliados entre nós, e dizer claramente que os nossos valores têm que ser mantidos por nós" (TUKANO, 2017 , p. 15). O tempo que o Brasil tem da chegada dos europeus conta com algum saldo positivo para a representação do indígena na literatura brasileira? É o questionamento de Graça Graúna (1999, p. 5) em seu texto "Um flagrante do marginalizado na literatura brasileira". Desde o "fatídico dia" da chegada dos portugueses, registrado textualmente pela pena de Caminha em sua Carta a El-Rei D. Manuel ao romance Macunaíma de Mário de Andrade, o índio brasileiro não andou tão bem afamado segundo Graúna ${ }^{6}$, pois as imagens negativas como "marginal", "espírito ruim", "indio cativo", "desprezo pelos mestiços", "indio perdedor", "subespécie", "mulher marginalizada" e "mulher abandonada" são recorrentes quando se representa o índio brasileiro ao lado do europeu. A autora conclui seu texto com uma mensagem otimista sobre a necessidade de "repensar o utópico [...] no sentido de valorizar esse conhecimento e respeitar a identidade do outro" (GRAÚNA, 1999, p. 5). Ter direito a este lugar utópico quer dizer que ele é tanto um espaço físico (demarcação, posse e/ou reconquista de terras tradicionais), quanto epistêmico (reconhecimento da língua, religião, cultura), pois a forma de dominação colonial perpassa por essas questões epistêmicas que envolvem a língua, a religião e a terra, como bem nota Silviano Santiago (2000, p. 14) em "O entre-lugar do discurso latino-americano", ao dizer que: "Evitar o bilinguismo significa evitar o pluralismo religioso e significa também impor o poder colonialista. Na álgebra do conquistador, a unidade é a única medida que conta".

O índio foi indexado ao poder do estado que se organiza pela via dessa unidade e passou a ser pensado como um incapaz, por isso a insistência em tutelá-lo. Mas Álvaro Tukano discorda gravemente; essa visão grosseira em relação aos povos indigenas tem contribuído apenas para diminuir sua voz e atar suas mãos:

Então, o que estou falando é para desatar esse pano que tem vedado as vozes das lideranças, as mãos das lideranças. Acho que o público tem que ouvir diretamente o que os verdadeiros lideres pensam, falam e defendem sobre a questão indigena (TUKANO, 2017, p. 26).

O índio brasileiro é o resultado do agressivo processo colonial, é ainda um sujeito que respira os ares produzidos pelo processo de colonização do Novo Mundo. O indigena americano é o Outro do europeu, por isso coube a ele o lugar do emudecimento, o lugar do subalterno. Penso aqui no sujeito subalterno segundo o aclamado ensaio da indiana Gayatri Spivak, Pode o subalterno falar? (2010), pois o indígena é um sujeito posto à margem dos sistemas de produção de conhecimento, um sujeito empurrado para a condição de subalterno, para a condição de tutelado pelo discurso alheio. Em março de 2018, Daniel Mundu-

\footnotetext{
6 Florência Garramuño (2017, p. 193), em "Imágenes de sobrevida", escreve o seguinte: "Desde la Carta de Caminha, 'el acta de nacimiento del Brasil', pasando por los sermões del Padre Vieira y el indianismo romántico, hasta llegar a la antropofagia brasileña y Macunaíma, la gran rapsodia ecléctica del pueblo brasileño - por nombrar solo las imágenes más canónicas -, el pueblo indígena y sus culturas han figurado de modo insoslayable en la cultura y la estética brasileña".
} 
ruku publicou o artigo "A literatura indígena não é subalterna" no Itaú Cultural. No texto, Daniel narra uma situação constrangedora sobre o lugar do índio nos festivais literários. Ele havia sido convidado como parte de uma cota para índio e negro para participar da Feira do Livro de Frankfurt, e além de ter sido subaproveitado no evento, teve a desconfortável experiência de assistir da plateia autores não índios falarem da temática indígena enquanto havia um escritor índio convidado para o evento. Não estou dizendo que somente o índio é autorizado a falar sobre a temática indigena, mas o caso posto por Daniel Munduruku ilustra uma situação em que seria legítimo, naquela circunstância, aproveitar a voz de um escritor que, além de ter mais de trinta livros publicados sobre a cultura indigena, é um índio Munduruku.

O subalterno não pode falar porque não há valor naquilo que ele tem a dizer. Eis a violência epistêmica, não ter direito à fala porque assim lhe é negado o exercício da autorrepresentação, pois ao tentar falar não encontra quem o possa ouvir. Não há diálogo, uma vez que o interlocutor está ausente. Subalterno é um sujeito sem voz. É sobre esse discurso minoritário que Homi Bhabha (2010a, p. 307) pensa o lugar do Outro nas grandes metrópoles ocidentais, neste caso, a Inglaterra. Tudo leva a crer que é este o lugar que o discurso hegemônico quer reservar ao indígena, um lugar silenciado. Por isso, não é difícil ser solidário ao pensamento de Daniel Munduruku (2018) quando ele diz: "não devo entrar no jogo do sistema que quer me usar para vender a mesma imagem que sempre levou para o exterior: subalternidade. Minha literatura não pode ser subalterna. Eu também não".

Quando iniciamos um estudo de textos originários de complexos culturais não ocidentais (ou extraocidentais) ${ }^{8}$, como é o caso dos textos criativos dos povos originários das Américas, convém, a priori, explicar o acesso a esses textos e em qual categoria literária vamos enquadrá-los, já que eles advém de um grupo não-hegemônico e, por isso, tende a ser invisibilizado. No presente estudo, os textos são as recriações poéticas para a língua portuguesa dos saiti do grupo indigena Marubo por Pedro de Niemeyer Cesarino (2013b), em parceria com os xamãs cantadores Armando Mariano Marubo, Antônio Brasil Marubo, Paulino Joaquim Marubo, Lauro Brasil Marubo e Robson Dionísio Doles Marubo, publicado no livro Quando a Terra deixou de falar. Não problematizarei o uso do termo poesia, poética ou estética para o texto aqui estudado, já que partindo de um grupo, como tantos outros, que não participam do mesmo legado cultural deixado pelas grandes civilizações europeias que incutiam um modo de pensar (e construir mundos) totalmente singular, largamente chamado de ocidental, corro o risco de minar o processo de criação marubo com valores ocidentais, não obstante a ressalva de utilizar (ou não) tais termos tenha implicações significativas no modo como se olha para um texto fora do complexo cultural greco-romano/ judaico-cristão. Dessa forma, a discussão aqui levantada ratificará a proposta de Risério (1993) de pensar os textos criativos indígenas enquanto um valioso capital simbólico para a "literatura brasileira".

A obra Quando a Terra deixou de falar possui treze saiti, dos quais destaco o canto Kaná kawã ("Raptada pelo raio”), entoado por Armando Mariano Marubo.

\footnotetext{
Disponível em: http://www.itaucultural.org.br/a-literatura-indigena-nao-e-subalterna. Acesso em: 25 abr. 2019.

8 Ver Lourenço (2005) para a proposta de um Ocidente a ocidente do Ocidente, ou Risério (1993) para as produções poéticas dos povos originários como criações extra ocidentais.
} 
Tanto a recriação quanto o original contém 529 versos divididos em 133 estrofes. As estrofes não são fixas, variam de um a quinze versos. A edição, vale acrescentar, é bilíngue e, fora a "Introdução" e os textos que principiam cada saiti, em cada página encontram-se duas colunas, à esquerda o texto em marubo e à direita a recriação em português.

Os saiti são longos cantos-mitos e, como textos criativos de viés poético, muito se assemelham à poesia narrativa, por isso sempre vamos observar um encadeamento de ações que, como no caso do "Raptada pelo raio" (Kaná kawã), culminará em um ensinamento. Posso adiantar a presença de uma fórmula utilizada na composição, que também serve de gatilho para a memória assegurar a coerência de textos que ultrapassam, em muitos casos, mil versos, quais seja, surgimento-deslocamento-estabelecimento (CESARINO, 2011, 2013b). Vale ressaltar que os saiti não são textos isolados, entre eles existe uma técnica de encaixe, explica Cesarino, que os cantadores utilizam para acoplar histórias, coube ao espírito inventivo do antropólogo/tradutor rearranjá-los nesse outro veículo de transmissão, o livro.

\section{Vozes Na floresta, A Pessoa segundo os Marubo}

Como explica Cesarino (2011, p. 33), o cosmos marubo é formado por uma miriade de seres que ocupam lugares diversos e se relacionam entre si como pessoas porque apreendem o mundo segundo um ponto de vista humano, agentes dotados de volição que podem assumir um ponto de vista humano em relação a um não-humano é discutido por Viveiros de Castro $(1996,2011,2015)$ a propósito do perspectivismo ameríndio e especificamente para o caso marubo em Cesarino (2011). Esses seres dividem-se em quatro grandes categorias, explica Cesarino (2011): os humanos, agentes das relações cotidianas, nesse caso os sujeitos marubo; as hiper-humanas (yove), espíritos que mantém boa relação com os humanos; os seres infra-humanos (yochî), também traduzidos por espectros por Cesarino, se os yove apresentam-se como bons, os yochĩ são seres com conotação negativa; e os seres extra-humanos, que englobam a categoria animal e vegetal. Se os agentes são diversos no cosmos marubo, a definição de corpo, por sua vez, carece de uma explicação particular, a citação é válida:

"Animal" e "humano" são entidades multifacetadas e devem ser entendidos com cuidado também. O que chamamos de animal é compreendido pelo pensamento marubo como uma configuração composta, por um lado, de "seu bicho" (awẽ yoĩni), "sua carcaça" (awẽ shaká) ou "seu corpo" (awẽ kaya) e "sua carne" (awẽ nami) e, por outro, de "sua gente/pessoa" (awẽ yora), isto é, o "seu duplo" (awẽ vaká), que é o dono (ivo) de seu bicho/carcaça/corpo. O emprego do possessivo (awẽ) é portanto essencial: um corpo é sempre de um determinado duplo (CESARINO, 2011 , p. 34).

Os duplos (vaká) são agentes outros (yove ou yochĩ, por exemplo) que habitam o corpo de determinada espécie. Os humanos podem possuir ou vir a possuir três vaká: chinã nató (vaká do coração), mechmirin vaká (vaká do lado direito) e mekiri vaká (vaká do lado esquerdo). Para os espíritos, o espaço interno da pessoa que eles habitam é a replicação do espaço externo, possuir esses duplos implica possuir "competências intelectuais e poéticas", a ausência deles 
denuncia a falta de pensamento, ou seja, a pessoa não sabe proferir os cantos. Os cantos são ensinados pelos espíritos (yove), eles os aprendem quando se ausentam do corpo/maloca/carcaça que habitam, e os ativadores essenciais dessas saídas são a ayahuasca e o rapé; ao sair do corpo os espíritos transitam pelo cosmos, aprendem os cânticos com outros agentes dotados de intencionalidade e os repassam para o sujeito corpo/carcaça, "uma vez em contato com os espíritos yovevo, mais sábios e loquazes que os humanos, a pessoa-carcaça se torna apta a memorizar e transmitir longos cantos tais como os saiti" $(\mathrm{CE}-$ SARINO, 2013b, p. 21-22). A seguir, encontra-se a ilustração que Alberto criou em 1983 para Delvair Melatti (1996, p. 112), que representa o corpo do xamã em transe ritual e nos dá uma ideia geral de como o xamã é pensado na episteme marubo como um corpo morada que abriga formas humanoides traduzidas por Cesarino como vaká.

Figura 1 - Xamã marubo

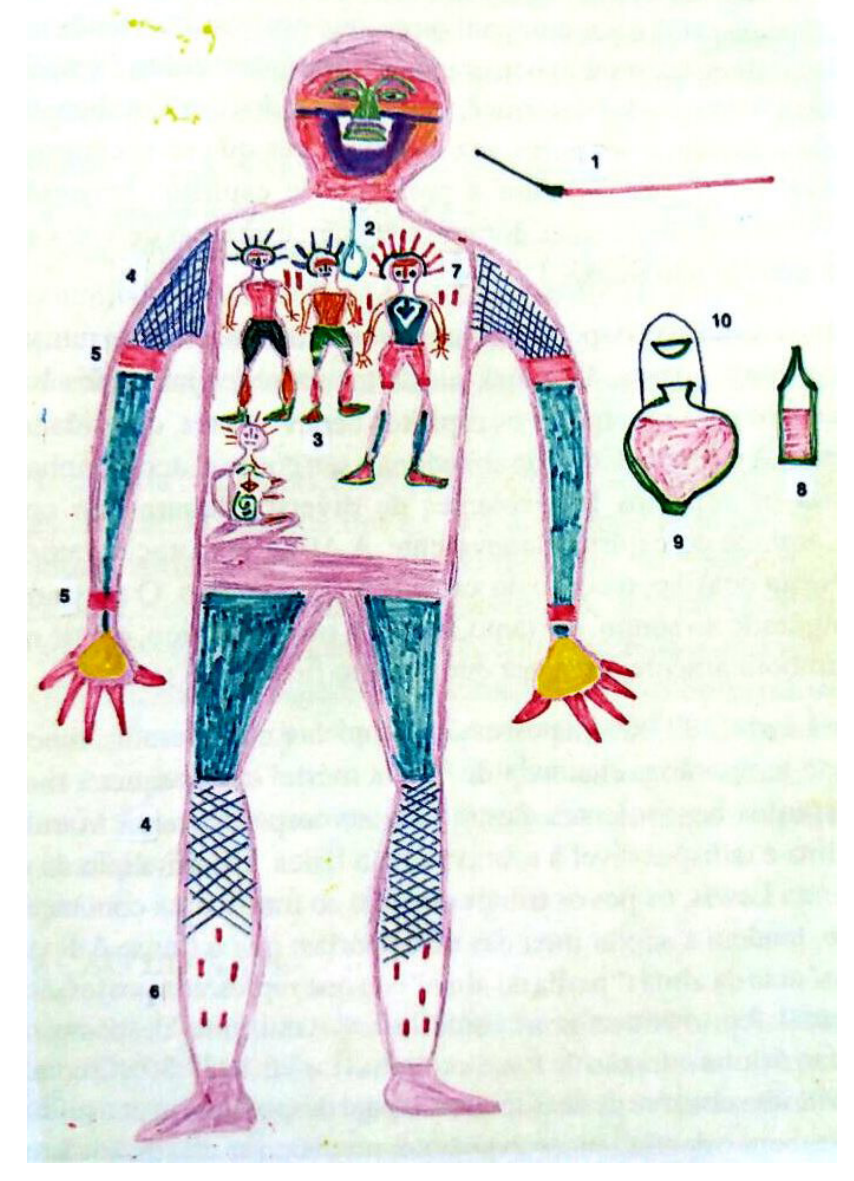

Fonte: Melatti (1996, p. 112). 
Os vaká residem em um espaço chamado de nokẽ shakĩ, traduzidos por "nosso oco". Fora do domínio corporal, shakĩ também se refere a um espaço interior passivel de ser preenchido, por exemplo, metaforicamente o espaço destinado aos rituais xamânicos dentro da maloca (txaitivo shakini), o mesmo se diz para ouvido, pachekiti shakĩ, o buraco ou oco da orelha (CESARINO, 2011, p. 36). Já a expressão nokẽ chinã, vida ou princípio vital, vertido como "nosso peitopensar" ou ẽ chinãnamã "em meu peitopensar", por Cesarino, corresponde ao local que abriga o coração. O antropólogo abre a ressalva de que tal tradução não abarca por completo a ideia proposta pelo termo chinã (grosso modo, pensar), o local indicado por ela é o peito, mas não exatamente a região física (shotxi), ou oĩti (coração físico). "A noção envolve uma referência espacial, na qual reside a coletividade de duplos habitantes da pessoa marubo responsável, em larga medida, pela performance intelectual da pessoa que o abriga" (CESARINO, 2011, p. 38-39), esse vaká, como vimos acima é o chinã nató.

Os pajés, yora chinãya, "gente pensadora", são os especialistas nesse pensamento visual dos deslocamentos e distâncias, característico da "fala pensada" ou chinã vana, que constitui os cantos de cura. Deslocam-se intencionalmente através do cosmos, aliás via suas almas ou duplos chinã nató, que vivem dentro da maloca/corpo (CESARINO, 2011, p. 39).

Dependendo dos seres, continua Cesarino, o duplo (vaká) pode não habitar a carcaça que lhe pertence, é o que acontece, por exemplo, com algumas espécies de animais e com todos os pássaros, os duplos vivem fora do corpo/maloca do animal, é no espaço externo que o duplo do animal ou do pássaro o vigia, e essa vigilância é mediada por "um longo caniço de inalar rapé, o rewe", é este o instrumento que permite ao duplo enquanto virtualidade acessar o seu corpo/ carcaça, por isso é comum um xamã marubo, ao se referir a um animal, classificá-lo como integrante do "povo azulão" ou como gente, o animal, nesse caso, é uma referencialidade para "sua coletividade personificada que vive em outra parte", aqui se coloca a ressalva de sempre se atentar para os lugares que ocupam os sujeitos no cosmos, caso contrário pode-se ferir o corpo/maloca de um vaká e, com isso, atrair a vingança, acarretando doenças. Os yove não possuem corpos/carcaças, são tidos como "puro duplo" (a vakáse), são, via de regra, bons, e responsáveis por auxiliarem os xamãs em seus rituais, tanto é que alguns xamãs são yove vake, "filho de espírito" ou yove romeya, "pajé-espírito" (CESARINO, 2011, p. 35). Desse modo, convém explicar, em linhas gerais, qual a definição de xamã a ser utilizada neste trabalho e a maneira como tal definição serve de elemento catalisador da performance.

\section{O OLHAR DUPLO DO XAMÃ 9}

A concepção de xamanismo, grosso modo, engloba "a capacidade manifestada por certos humanos de cruzar as barreiras corporais e dotar a perspectiva de subjetividades não-humanas" (VIVEIROS DE CASTRO, 2011, p. 468), assumir um ponto de vista outro nos faz pensar no deslocamento que possibilita a tradução do xamã. Uma movência que implica o sair de si e do seu espaço, pois "a

9 O xamã romeya é aquele que envia seu duplo para longe do corpo enquanto recebe outros espíritos que, por sua vez, cantam por meio do corpo/carcaça do xamã (CESARINO, 2011). 
marca ou estigma da tradução em geral é o fato de ela ser uma passagem: de um texto para outro, de um espaço para outro, de um tempo para outro" (SELIGMANN-SILVA, 2005, p. 189).

Como bem observou Bhabha (2010b, p. 25), Salman Rushdie, em Os Versos Satânicos, diz "que o olho mais fiel pode agora ser aquele da visão dupla do migrante", do elemento exógeno que executa um deslocamento. É o espaço limiar que permite àquele que vem de fora assumir uma posição privilegiada, no sentido de proporcionar ao grupo a passagem para outra visão de mundo, ao modo como observa Carneiro da Cunha (2009) sobre o lugar ocupado pelo xamã, aquele que conhece mundos distintos e, por isso, permite a comunicação entre eles. O interstício é o lugar do xamã que procuro definir, o entre-lugar de Bhabha (2010a). Nesse contexto cabe as considerações de Seligmann-Silva (2005, p. 190) acerca da "saída do indivíduo de si mesmo" em busca de outro, de um "não-eu", como condição primeira do sujeito "constitui[r]-se em oposição ao mundo". O que nos leva a considerar que incorporar o (passar pelo) outro é um modo de revigorar-se, mas também um modo de reconhecimento pela diferença. Nesse mesmo tom, Gagnebin (2009, p. 26) observa que poetas e adivinhos (acrescento o xamã) assemelham-se na medida em que são aptos a verem "o invisivel, o passado e o futuro que os outros homens clarividentes não enxergam".

Essas definições englobam aquele conceito traçado por Viveiros de Castro (2011, p. 462) acerca do xamanismo/antropofagia, no qual são tidos como próximos já que envolvem

[...] um processo de transmutação de perspectivas, onde o devorador assume o ponto de vista do devorado, e o devorado, o do devorador: onde o "eu" se determina como "outro" pelo ato mesmo de incorporar este outro, que por sua vez se torna um "eu".

D'Abbeville, na seguinte passagem, expõe esse colocar-se como no momento em que os actantes devorador e devorado trocam as ofensas que realimentam a vingança, base do canibalismo ritual tupinambá de acordo com Carneiro da Cunha e Viveiros de Castro (2009):

Não sabes que tu e os teus mataram muitos parentes nossos e muitos amigos? Vamos tirar a nossa desforra e vingar essas mortes. Nós te mataremos, assaremos e comeremos [...] Tu me matarás, porém eu já matei muitos companheiros teus. Se me comerdes, fareis apenas o que já fiz eu mesmo. Quantas vêzes me enchi com a carne de tua nação! Ademais, tenho irmãos e primos que me vingarão (D’ABBEVILLE, 1945 [1614], p. 232).

É nesse sentido que Viveiros de Castro (2011, p. 462) reafirma que o objetivo do canibalismo ritual dos tupinambá estava menos para alcançar a essência do inimigo que para ocupar o lugar do devorador "e, portanto, sua condição de inimigo", é permutando lugares que se adota outro ponto de vista. Intercambiar posições, o que revela um antagonismo latente na cosmologia indígena, também é verificado no xamanismo araweté, no qual há "essencialmente um dispositivo de intercâmbio entre os viventes e os Maï. Os humanos dão de comer aos deuses, no sentido alimentar como no sexual, recebendo em troca cantos (a 'música dos deuses' cantada pelos xamãs)” (VIVEIROS DE CASTRO, 2011, p. 269). 
Entre os Wari', Vilaça (2006, p. 202-205) diz que o "xamã (ko tuku ninim) é 'aquele que vê"', que seu corpo é duplo, que ele é tanto humano quanto animal. Essa peculiaridade do corpo do xamã contribui para que ele participe de dois éthos, humano e animal. Dessa maneira, quando ele está entre os wari', os animais se apresentam como tal, ou seja, como animais, a percepção se altera radicalmente quando o xamã participa do éthos animal, os animais se apresentam como humanos (wari), enquanto os humanos tornam-se animais aos olhos do xamã. Na sociedade Wari', a presença do xamã favorece ao grupo um ponto de vista diferenciado, opondo-se ao matador tupinambá de Carneiro da Cunha e Viveiros de Castro (2009), como explica Vilaça, ele permite um olhar outro acerca do mundo que habita, o lugar do devorado, não do devorador.

É com base nesse conceito, da visão dupla de "alguém que tem olhos" e que deseja ver, cujos olhos "estão 'abertos' para o 'dom' da visão \& da canção", que Rothenberg (2006, p. 31-32) define o xamã como o primeiro poeta, não por menos "sua técnica depende da criação de circunstâncias linguísticas especiais, i.e., da canção \& evocação". Esse lugar diferenciado do vidente, do elemento exógeno, confirma-se em uma característica que define o xamã como sujeito movente, "em todo o ocidente amazônico, os xamãs, como se sabe, são os viajantes por excelência” (CARNEIRO DA CUNHA, 2009, p. 106).

Em Cesarino encontramos no saiti sobre o Pajé Flor de Tabaco (Rome Owa Romeya) a relação entre xamãs (Pajé Flor de Tabaco, Pajé-Urubu e Pajé-Sucuri), que explica a posição privilegiada do pajé indígena. Após a morte, Flor de Tabaco decide não ser queimado, condição que não afeta seu duplo, diferente da cremação observada com a esposa raptada em "Raptada pelo raio", no entanto, é no direcionamento que Flor de Tabaco dá ao seus filhos que observamos a metáfora explicativa dos rios com os xamãs: “Newere amairisho' Subam na direção/'Yove waka revo' Do alto Rio-Espírito/'Revo vosoinai' Onde rios se cruzam/[...] 'Akatõ vekõi' Entre três rios/'A shokosho' Ali vivam/'Ea nĩkãtatsoma!' Atentos a mim!" (CESARINO, 2013b, p. 197-198).

Observem, por exemplo, o verso "Yove waka revo", no qual o rio (revo) pertence aos domínios dos espíritos yove que, como vimos, trata-se dos espíritos benfazejos que auxiliam os xamãs em seus cantos de cura. Outro verso de igual relevância é "Revo vosoinai", traduzido por Cesarino como "Onde rios se cruzam", ponto de confluência e junção análogo à função do pajé, local de convergência das múltiplas vozes que ecoam nos diversos domínios do cosmos marubo, pois está implícita nessa relação de subjetividades a relação de montante à jusante (CARNEIRO DA CUNHA, 2009), própria do pajé indígena, nesse contexto, espiritizar (yovea) é a forma de acessar outros mundos, é uma maneira de inserir percepções sensoriais naquilo que se conta.

\section{O gUe SE ESCUTA NA FLOREsta, OS SAITI}

Todos os aspectos sensoriais que tocam a plateia fazem parte da canção. Com tal observação, Zumthor (2014, p. 32) fala de "uma 'forma': não fixa nem estável, uma forma-força, um dinamismo formalizado" para definir a performance como o colocar em ação uma experiência sinestésica. Nesses termos, a performance é uma ação que geralmente comunica um texto por meio de um conjunto de fatores que sensibiliza o corpo, sobretudo enquanto uma produção sonora e 
gestual, uma fala em movimento, uma situação que não esteriliza o momento porque o torna único, transitório e efêmero. Por isso que aquilo que se comunica poeticamente, "texto, sonoridade, ritmos, elementos visuais" (ZUMTHOR, 1993, p. 220) possivelmente audiveis e visiveis, compreende o que Zumthor define como obra, a totalidade dos elementos que compõe a execução de um ato. Nesse palco, emitente e receptor encontram-se em confronto, mas apenas isso não é suficiente para colocar o texto/poema em funcionamento, o que se profere e o que se escuta soma-se ao "todo da performance que constitui o lócus emocional em que o texto vocalizado se torna arte e donde procede e se mantém a totalidade das energias que constituem a obra viva" (ZUMTHOR, 1993, p. 222). Há um aflorar de sentimentos, o outro não é impassivel, é dele requerido um envolvimento para que os elementos se completem. Claro que para a performance operar o texto é necessário que ele esteja inserido dentro de um grupo, pois, fora dele, "o sentido esvai-se: texto é texto para aqueles que o esperam e, de certo modo, dele têm necessidade" (ZUMTHOR, 1993, p. 226), performance, nesse caso, é acontecimento, pois implica aceitar a presença de um campo de concordância.

Os saiti, entre outros, são artes verbais que necessitam da presença de um corpo, o que implica corporeidade coloca em destaque a voz viva do performer/ cantor/xamã marubo, os saiti são antes de tudo poesia vocal por desprezarem a fala das relações cotidianas (veyô vana) e se valerem da "fala metafórica", bela, correta (roaka), não exatamente por ser altamente eficiente para o ritual, mas por ser "um modo de conhecimento e de respeito (ese), uma maneira de revelar relações e formas de surgimento através, diriamos nós, da elaboração poética”, como explica Cesarino (2013a, p. 451).

Vejamos um excerto do canto "Kaná kawã, 'Raptada pelo raio", cantada por Armando Mariano Marubo e traduzida por Pedro Cesarino:

1

Vo Shono Romeya
Yove kaya apai
Awẽ nimẽaitõ
Ino Sheta Rekẽne
Ino Sheta Wesí
Ayo Chai inisho
Yove vana kẽsho
Sheni vana netãti
Sheni vana nokoi
Pajé Samaúma
Pajé mais forte
Ali sempre vivia
Mas Sheta Rekẽ
Sheta Wesí
E Ayo Chai
Ao pajé invejam
Soprocanto fazem
E chega o soprocanto

Esses são os primeiros versos do saiti que relatam a cisão do relacionamento do Pajé Samaúma (Shono Romeya) com sua esposa Yene Maya por conta dos sentimentos cobiçosos dos espíritos yochĩ (Sheta Rekẽ, Sheta Wesi e Ayo Chai). O termo "sheni vana", recriado por Cesarino como "soprocanto", é um exemplo de uso metafórico das palavras que o antropólogo utiliza como meio de traduzir os cantos, pois ficamos sabendo em nota que literalmente significa "fala de velho", a fala dos mais experientes na arte vocal marubo.

O rompimento do casal se dá pela morte da Yene Maya (a esposa grávida) por um raio enviado pelos yochĩ. Tal morte causa a cisão do duplo da esposa do Pajé Samaúma que vai morar nos domínios dos espíritos agressores, é a busca de Shono Romeya pelo duplo de Yene que colocará em cena o deslocamento do 
pajé marubo nos diversos domínios a serem percorridos. Como observa Cesarino (2011), esse canto é classificado como oniska, ou seja, melancólico, triste, cuja lamentação do pajé pode ser observada no jogo imagético abaixo:

$\begin{array}{lll} & \text { Awẽ aĩ toya } & \text { Sua mulher grávida } \\ 20 & \text { Kaná kawã yochĩni } & \text { Os espíritos do raio } \\ & \text { Shatẽkamaĩnõ } & \text { Rasgam e retalham } \\ \text { A veroyakĩki } & \text { E ela tomba } \\ \text { Pakei kawãmãi } & \text { Diante do marido } \\ & \text { Awẽ anõ aĩki } & \text { Que assim ampara } \\ & \text { Tetsõ pakei kashõki } & \text { A mulher desfalecida } \\ & \text { Waishõ aoi } & \text { E começa a chorá-la }\end{array}$

$\mathrm{Na}$ obra estão vertidas para o português treze narrativas cantadas, "Kaná kawã" é um saiti, um episódio narrativo, todos são cuidadosamente "metrificados e versificados, capazes de se estenderem por dezenas de milhares de versos" (CESARINO, 2013a, p. 460), esse que apresento é composto de 529 versos, está publicado em Cesarino (2013b) e segue uma armadura narrativa estruturada em três momentos, segundo o antropólogo/tradutor: motivação, deslocamento e estabelecimento, regra que serve de baliza quando o xamã entoa a canção. Poesia se paga com poesia. Ou de outro modo. A melhor forma de se traduzir um texto criativo é compondo outro texto criativo correspondente. Foi tal ideia que direcionou as traduções de Cesarino, cuja recriação também acompanha a carência de conectivos e replica a estrutura sintática sujeito-complemento-verbo da poesia marubo, a opção pelo uso mínimo de pontuação e conectivos acaba por condensar as imagens de cada verso, criando uma tessitura que potencializa o valor metafórico da recriação. O paralelismo também é um recurso que não passa despercebido. Para acessar o cosmos, o pajé necessita ingerir substâncias ativadoras do transe xamânico, como por exemplo ayahuasca e rapé, algo que se verifica no desenrolar do saiti, que possibilita o deslocamento do herói nos demais estratos cósmicos dentro do canto, replicando na poética o que acontece no imanente da maloca, é o que observamos nos versos abaixo:

$\begin{array}{lll} & \text { Iki chinãvaiki } & \text { Aos parentes diz } \\ & \text { Makã tachi pei } & \text { E folha forte } \\ & \text { Peikia tsoasho } & \text { A folha coa } \\ & \text { Yaniaki avai } & \text { Do caldo bebe } \\ 55 & \text { Awẽ yovekãia } & \text { Em espírito muda-se } \\ & \text { Kanã Mari sheni } & \text { E vai descendo } \\ & \text { Anõ iti vaĩse } & \text { Ali no caminho } \\ & \text { Yove pake aoi } & \text { Do velho Kanã Mari } \\ & \text { Imi tama sheni } & \text { E no Tronco-Sangue } \\ & \text { A nokopakesko } & \text { Ali vai chegando }\end{array}$

Se para o xamã cantador que salmodia os versos do saiti é motivado pelo uso do ayahuasca e do rapé, o mesmo acontece com o herói na poética cantada. Pajé Samaúma avança nos domínios de outras subjetividades, vendo-as como elas se veem por conta da "folha forte" cujo "caldo bebe". Vejamos os momentos de encontro com os diversos agentes dotados de volição que povoam o cosmos marubo: 


$\begin{array}{ll}59 & \text { Imi tama sheni } \\ 83 & \text { Ene yochĩ nawavos } \\ 97 & \text { Kasotamá iriõ } \\ 126 & \text { Wasi chai yochĩvo } \\ 133 & \text { Atsã chai yochĩvo } \\ 140 & \text { Shõpã chai yochĩvo } \\ 147 & \text { Manĩ chai yochĩvo } \\ 152 & \text { Washmẽ chai yochĩvo } \\ 161 & \text { Chiwã chai yochĩvo } \\ 168 & \text { Mera chai yochĩvo } \\ 175 & \text { Chiwã chai yochĩvo } \\ 177 & \text { Chai Yove Nawavo } \\ 188 & \text { Wanĩ chai yochĩvo } \\ 195 & \text { Nisti chai yochĩvo } \\ 234 & \text { Shono Yove Nawavo } \\ 250 & \text { Shai Yove Nawavo } \\ 292 & \text { Shane Nea shokoa } \\ 307 & \text { Moka tama voroke } \\ 311 & \text { Siná voĩ niáki } \\ 343 & \text { Kaná Naí Shavaya }\end{array}$

E no Tronco-Sangue
E gente d'água
Da árvore-espírito
E gente pássaro-capim
E gente pássaro mandioca
E gente pássaro-mamão
E gente pássaro-banana
E gente pássaro-algodão
E gente pássaro-erva
E outra gente-pássaro
E gente pássaro-planta
E Povo Pássaro-Espírito
E gente pássaro-pupunha
E gente pássaro-paxiúba
E Povo Espírito da Samaúma
E Povo Espírito da Envireira
Na gente Jacamim-Azulão
Gente lagarto-amargo
Ali nos Pica-Paus-Bravo
E ao Céu-Raio

Tal qual o paralelismo, a poética marubo recorre a construções sintáticas que valorizam o discurso paratático enquanto um recurso estético caro ao processo de criação dos xamãs cantadores. Por isso, é possível encontrar sentenças curtas e semelhantes criando aquele ar de déjàvu. Há certa dosagem no encadeamento das ações, evita-se um discurso rebuscado. Daí as sentenças serem linguisticamente pouco complexas, semelhante a um filme de cenas breves e entrecortadas. São sentenças coordenadas de poucos recursos e conexões que, além da presença marcante da oralidade - característica singular do texto indígena -, produzem um grande sentido lógico na construção xamânica por sintetizar uma série de imagens ao repassar uma mensagem poético-instrutiva.

O saiti é o exercício de experiência com o outro que a plateia só pode experimentar por meio da entoação do xamã, canto que é conhecimento. Os versos presentificam valores que podem ser acessados por meio da pessoa do xamã cantador, elo que fortalece o contato com mundos aparentemente disjuntos. Performance nesses termos apresenta-se como um acontecimento social, já que agrega.

Se performance denota voz e movimento, ela implica sobremodo competência, "um saber-ser no tempo e no espaço", o que coloca o corpo como responsável por nos realocar em um tempo e lugar bem marcados, "a voz proclama, emanação do nosso ser", diz Zumthor (2010, p. 166). É o que explica Cesarino (2013b, p. 23), recriar no hic et nunc da performance uma experiência vivenciada alhures e transmiti-la a uma plateia dentro de uma comunidade narrativa requer, sobretudo, um intenso "investimento de memória, afeto e relação". Essa observação me leva a concluir que a performance engloba um processo sinestésico, digo, ela opera a obra, pois consegue desencadeá-la por meio de um corpo.

A voz entoada ganha corpo quando acompanhada dos elementos não verbais, que formam aquilo que Zumthor (1993) define como performance, ou melhor, a voz é corpo, tendo em vista que neste se realiza enquanto obra, e os saiti dos Marubo são exemplos de artes verbais indígenas que coadunam poética, canto 
e performance ao se expressarem pelo corpo do xamã. O trabalho desenvolvido por Cesarino é um rico material para se compreender a noção de pessoa entre os Marubo, o que acarreta entender as múltiplas vozes que ecoam nos seus cantos, além de ser um grande exercício de tradução como recriação. Por se tratarem de cantos sagrados, com uma linguagem refinada, rica em metáforas que os tornam quase inacessiveis aos integrantes comuns do grupo, aos não iniciados nas artes da voz, esses cantos xamânicos muito se assemelham às artes verbais dos guaranis (CLASTRES, 1990), se igualam na medida em que os dois casos são "belas palavras".

Se a arte da voz exige a presença de um corpo para se atualizar, e presença aqui é compreendida como a concomitante relação entre as sensações corporais e os afetos, coloca-se em oposição a ele outro que é recepção, daí a voz não dar-se no vazio, há a prerrogativa de que ela seja compartilhada no aqui e agora da performance. Com isso, quero dizer que os saiti entram na dinâmica da movência, principalmente por serem marcados pelo deslocamento do vaká. O que é a palavra vocalizada e a voz poética de um grupo que valoriza o deslocamento expresso em uma miriade de agentes cósmicos, igualmente nômades, se não a criação de uma arte verbal altamente singular que é o nomadismo?

\section{INDIGENOUS PROTAGONISM, SHAMANISM AND POETIC CREATION}

Abstract: The recent advancement in indigenous authorship publications is a fact to be celebrated, both for the engagement of Amerindian communities in building their history as writing becomes a political entry into the Western world. If historically their values have been despised, with the writing the indigenous assumes their own voice. Understanding that in the Amazon there is a non-Western protagonism of poetic creation, this work aims to present some characteristcs of the saiti marubo and relate them to shamanism according the translation presented by Cesarino in the book Quando a Terra deixou de falar. The saiti are long songs-myths, creative texts of poetic style that are structured according to a formula of composition, as Cesarino notes, the emergence-displacement-establishment.

Keywords: Shamanism. Indigenous protagonism. Poetic creation.

\section{REFERÊNCIAS}

ACHUGAR, H. Planetas sem boca: escritos efêmeros sobre arte, cultura e literatura. Belo Horizonte: EDUFMG, 2006.

BHABHA, H. K. Como o outro entra no mundo: o espaço pós-moderno, os tempos pós-coloniais e as provações da tradução cultural. In: BHABHA, H. K. O local da cultura. Belo Horizonte: EdUFMG, 2010a. p. 292-325.

BHABHA, H. K. Locais da cultura. In: BHABHA, H. K. O local da cultura. Belo Horizonte: EDUFMG, 2010b. p. 19-42.

CARNEIRO DA CUNHA, M. C. Xamanismo e tradução: pontos de vista sobre a floresta amazônica. In: CARNEIRO DA CUNHA, M. C. Cultura com aspas. São Paulo: Cosac Naify, 2009. p. 101-122. 
CARNEIRO DA CUNHA, M. C.; VIVEIROS DE CASTRO, E. V. Vingança e temporalidade: os Tupinambá. In: CARNEIRO DA CUNHA, M. C. Cultura com aspas. São Paulo: Cosac Naify, 2009. p. 77-99.

CESARINO, P. N. Oniska: poética do xamanismo na Amazônia. São Paulo: Perspectiva; Fapesp, 2011.

CESARINO, P. N. Cartografias do cosmos: conhecimento, iconografia e artes verbais entre os marubo. Mana, Rio de Janeiro, v. 19, n. 3, p. 437-471, 2013a. CESARINO, P. N. Quando a Terra deixou de falar: cantos da mitologia marubo. São Paulo: Editora 34, 2013b.

CLASTRES, P. A sociedade contra o estado. In: CLASTRES, P. A sociedade contra o Estado: pesquisa de antropologia politica. Rio de Janeiro: Francisco Alves, 1988. p. 132-152.

CLASTRES, P. A fala sagrada: mitos e cantos sagrados dos índios Guarani. Campinas: Papirus, 1990.

D’ABBEVILle, C. História da Missão dos Padre Capuchinhos na Ilha do Maranhão e terras circunvizinhas: em que se trata das singularidades admiráveis e dos costumes estranhos dos índios habitantes do país. São Paulo: Martins Editora, 1945 [1614].

DURHAM, E. R. O lugar do índio. In: DURHAM, E. R. A dinâmica da cultura: ensaios de antropologia. São Paulo: Cosac Naify, 2004. p. 297-305.

GAGNEBIN, J. M. Lembrar escrever esquecer. São Paulo: Editora 34, 2009.

GARRAMUÑO, F. Imágenes de sobrevida: figuraciones del Pueblo yanomami en el arte contemporáneo. El Taco em la Brea, ano 4, v. 6, p. 191-200, 2017.

GRAÚNA, G. Um flagrante do marginalizado na literatura brasileira. Porantim, Brasília, n. 216, p. 5, jul. 1999.

GRAÚNA, G. Contrapontos da literatura indigena contemporânea no Brasil. Belo Horizonte: Mazza Edições, 2013.

LOURENÇO, E. O Ocidente e a sua deriva final. In: LOURENÇO, E. A morte de Colombo: metamorfose e fim do Ocidente como mito. Lisboa: Gradiva, 2005. p. 9-17.

MELATTI, D. M. A morada das almas: representação das doenças e das terapêuticas entre os Marúbo. Belém: Museu Paraense Emílio Goeldi, 1996.

MONTE, N. L. Escolas da floresta: entre o passado oral e o presente letrado. Rio de Janeiro: Multiletra, 1996.

MUNDURUKU, D. A literatura indígena não é subalterna. Itaú Cultural, São Paulo, 16 mar. 2018. Disponivel em: http://www.itaucultural.org.br/a- literatura-indigena-nao-e-subalterna. Acesso em: 25 abr. 2019.

RISÉRIO, A. Textos e tribos: poéticas extraocidentais nos trópicos brasileiros. Rio de Janeiro: Imago, 1993.

ROTHENBERG, J. Etnopoesia no milênio. Rio de Janeiro: Azougue Editorial, 2006.

SANTIAGO, S. O entre-lugar do discurso latino-americano. In: SANTIAGO, S. Uma literatura nos trópicos: ensaios sobre dependência cultural. Rio de Janeiro: Rocco, 2000. p. 9-26. 
SELIGMANN-SILVA, M. O local da diferença: ensaios sobre memória, arte, literatura e tradução. São Paulo: Editora 34, 2005.

SPIVAK, G. C. Pode o subalterno falar? Belo Horizonte: EDUFMG, 2010.

TERENA, M. A sociedade branca é uma capa que o índio usa para sobreviver. Folha de S.Paulo, São Paulo, 3 maio 1981. Caderno Folhetim, p. 5.

TUKANO, Á. Tembetá: Álvaro Tukano. Rio de Janeiro: Beco do Azougue, 2017.

TUKANO, A. Álvaro Tukano conta a luta dos povos indígenas no Brasil. Pernambuco - Suplemento Cultural do Diário Oficial do Estado, 6 set. 2018. Disponivel em: http://www.suplementopernambuco.com.br/inéditos/2156-álvaro-tukano-conta-a-luta-dos-povos-ind\%C3\%ADgenas-no-brasil.html. Acesso em: 14 maio 2019.

VILAÇA, A. Quem somos nós: os Wari' encontram os brancos. Rio de Janeiro: Editora UFRJ, 2006.

VIVEIROS DE CASTRO, E. V. Os pronomes cosmológicos e o perspectivismo ameríndio. Mana, Rio de Janeiro, v. 2, n. 2, p. 115-144, 1996.

VIVEIROS DE CASTRO, E. V. A inconstância da alma selvagem: e outros ensaios de antropologia. São Paulo: Cosac Naify, 2011.

VIVEIROS DE CASTRO, E. V. Perspectivismo. In: VIVEIROS DE CASTRO, E. V. Metafisicas canibais: elementos para uma antropologia pós-estrutural. São Paulo: Cosac Naify, 2015. p. 33-54.

ZUMTHOR, P. A letra e a voz: a "literatura" medieval. São Paulo: Companhia das Letras, 1993.

ZUMTHOR, P. Introdução à poesia oral. Belo Horizonte: Editora UFMG, 2010.

ZUMTHOR, P. Performance, recepção, leitura. São Paulo: Cosac Naify, 2014.

Recebido em 4 de março de 2018. Aprovado em 18 de março de 2019. 